\title{
Impact of Cluster Front Line Demonstrations on Productivity and Profitability of Chickpea in Desert of Rajasthan, India
}

\author{
Hrish Kumar Rachhoya ${ }^{1 *}$, Mukesh Sharma ${ }^{2}$ and V. K. Saini ${ }^{1}$ \\ ${ }^{1}$ Department of Agronomy, Krishi Vigyan Kendra, (GVM), Sardarshahar, District-Churu -1 \\ (Rajasthan)-334003, India \\ ${ }^{2}$ Department of Plant Protection, Krishi Vigyan Kendra, (GVM), Sardarshahar, District- \\ Churu -1 (Rajasthan)-334003, India \\ *Corresponding author
}

\section{Keywords \\ Cluster front line demonstration, \\ Technology gap, \\ Extension gap, \\ Technology index, Chickpea}

Article Info

Accepted:

18 May 2018

Available Online:

10 June 2018

\section{A B S T R A C T}

Churu comes under Desert region of Rajasthan and agriculturally it is very important district. In Churu chickpea cultivation is very common but its productivity is very low. To establish the production potential of crop Cluster Front Line Demonstrations (CFLDs) is an appropriate tool. To increase the production and productivity of gram in the district, Krishi Vigyan Kendra, Gandhi Vidya Mandir, Sardarshahar, Churu-1(Rajasthan) conducted 125 demonstrations on gram during 2015-16 to 2016-17 in four adopted villages. The critical inputs were identified in existing production technology through farmers meeting and group discussions with the farmers. Average yield data of conducted CFLDs revealed that, higher yield (1767 kg ha-1) was obtained in demo plot over local check (1364 kg ha-1) and additional yield in demo plot was obtained $403 \mathrm{~kg}$. Percent increase over local check was found $29.54 \%$. Average extension gap, technology gap and technology index were found 402.33, 433.33 kgha-1 and 19.69\% respectively. Averages of gross and net returns of demonstration were 29.17 and $42.69 \%$ higher than the farmers' practice respectively. Most important factor B: C ratio indicates that whether CFLD technology is profitable or not. B: C ratio was found higher throughout the study and average was (3.10) in demonstration over local check (2.58). Review of data on incidence of disease in crop revealed that, percentage of damaged plant (9.83) was lower in demonstration as compared to (17.10) under farmers' practice. Spraying of Quinolphos 25 EC @ $2.0 \mathrm{ml} /$ liter water at the pod initiation stage reduces pod borer attack, consequently lesser infected pods (2.37) in demo as compared to farmers' practices (7.9). Result suggested economic viability and agronomic feasibility of the CFLD technology for gram cultivation.

\section{Introduction}

The per capita net availability per day of pulses is still low in India, ranging from 42-47 gram. It is almost stagnating with slight increase in recent years. This is due to the increase in population and almost stagnation in production of pulses. Despite the spiraling prices of pulses, the area and production of pulses has not changed much during the last many years. Area under pulses ranged between 23 - 25 million hectares and 
production 15- 19 million tonnes in India. The current productivity of pulses varied from 700-790 kg/ha. Although there is slight increase in pulse productivity in recent times, but it is still well below the world's average productivity $(840 \mathrm{~kg} / \mathrm{ha})$. Interestingly India is the largest producer, importer and consumer of Pulses in the world. Pulses occupy a prominent place in human nutrition particularly among the lower income groups of people in developing countries like India. Important pulses grown in India are chick pea (bengal gram), pigeon pea (red gram), lentil (masur), urd bean (black gram), moong bean (green gram), moth bean, pea, grass pea (khesari), cow pea (lobia) and broad bean (faba bean), etc. These grains are relatively inexpensive source of protein in developing countries where protein energy malnutrition is quite common. The protein content in pulse grains generally ranges from $20-25 \%$. Besides protein, pulses are also a good source of dietary fibre, starch, minerals and vitamins. Legumes are typically low in fat, contain no cholesterol, and are high in folate, potassium, iron and magnesium. A good source of protein, legumes can be a healthy substitute for meat, which has more fat and cholesterol. Legumes are included in all 'food baskets' and dietary guidelines. The World Food Programme (WFP) for instance includes 60 grams of pulses in its typical food basket, alongside cereals, oils, sugar and salts. Encouraging awareness of the nutritional value of legumes can helps consumers adopt healthier diets. Legumes are an important component of crop rotations, they require less fertilizer than other crops and they are a low carbon source of protein. They have a direct positive impact on soil quality because they help feed soil microbes, which helps in improving soil health. They have also been shown to produce greater amounts of different amino acids than non-legumes and its plant residues have a different biochemical composition than other crop residues. There are many legumes traditionally used as dal and many of them now being utilized as vegetables. There are several reasons responsible for declining the productivity of pulses is; more focus on cereal crops e.g. wheat \& rice, less investment on irrigation facilities (only $15 \%$ for pulses as against 80 $90 \%$ for wheat/ rice), technological absence to minimize disease, insect and weed infestation, that caused substantial damage (30\%) in standing crops, green revolution just by passed the pulses and hence the use of HYVs for pulses was never encouraged, lack of quality seed of improved varieties, cultivation on less fertile soil, rain fed and marginal lands, imbalance use of nutrient, lack of integration of nutrient supply sources and adverse impact of weather aberrations on crops. In general the productivity of gram crop in Churu is low because of least technological backup, small and marginal land holdings and poor adoption of improved package of practices. Therefore, efforts have been made through Cluster Front Line Demonstrations (CFLDs) to introduce innovative package of practices of gram with a view to increase its productivity in the district.

\section{Materials and Methods}

The present study was carried out by the Krishi Vigyan Kendra, Gandhi Vidya Mandir, Sardharshahar, Churu-1 (Rajasthan) during rabi season from 2015-16 to 2017-18 (03 years) at the farmers' fields of different ten villages of Churu of Desert of Rajasthan. In total 250 frontline demonstrations in 100 ha area in different villages were conducted. Materials for the demonstrations with respect to CFLDs and farmers' practices were given in Table 1. Impact of cluster front line demonstrations chickpea in desert of churu-1, Rajasthan

In case of farmers practice plots, existing practices being used by farmers were followed. In general, soils of the area under 
study were sandy in texture and medium to low in fertility status. The CFLDs were conducted to study the gaps between the potential yield and demonstration yield, extension gap and technology index. In the present evaluation study, the data on out- put of chickpea cultivation were collected from CFLD plots, besides the data on local practices commonly adopted by the farmers of this region were also collected. In demonstration plots, a few critical inputs in the form of quality seed, Bio-fertilizers, weedicide etc. were provided and nonmonetary inputs like timely sowing in lines and timely weeding were performed. Where, in farmers practice traditional practices prevailing in the area were maintained. The demonstration farmers were facilitated by KVK scientists in performing field operations like sowing, spraying, weeding, harvesting etc. during the course of training and visits. The technologies demonstrated are mentioned in Table 1 and compared with local practices. The satisfaction level of participating as well as neighboring farmers' for the performance of improved variety demonstrated was also assessed. The economic-parameters (Gross return, net return and $\mathrm{B}: \mathrm{C}$ ratio) were worked out on the basis of prevailing market prices of inputs and Minimum Support prices of outputs.

\section{Results and Discussion}

\section{Yield}

The data (Table 2) indicated that the Cluster front line demonstration has given a good impact over the farming community of Churu district as they were motivated by the new agricultural technologies applied in the demonstrations. Results of 250 Cluster frontline demonstrations indicated that the cultivation practices comprised under CFLD viz., use of improved variety (GNG-1581), balanced application of fertilizers (N: P: K @
20:32:20:40 kg NPKS ha-1 with $16 \mathrm{~kg}$ ZnSO4), line sowing, timely weed management and control of chickpea Pod borer through insecticide, produced on an average $1721 \mathrm{~kg} / \mathrm{ha}$ chickpea yield, which was $29.63 \%$ higher compared to prevailing farmers practice (1328 kg/ha). Kumar and Yadav (2007) also reported that recommended dose of phosphorus and sulphur increase the yield and quality of chickpea.

\section{Sell price of mustard averaged three years 3200 Rs. per quintal}

The technology gap, extension gap and technology index were calculated using the following Formulae given by (Samui et al., 2000).

Technology gap = Potential yield Demonstration yield

Extension gap $=$ Demonstration yield - yield under existing practice

Technology index $=\{($ Potential yield Demonstration yield)/Potential yield $\}$ x 100

Potential yield of mustard variety GNG-1581 is $2300 \mathrm{~kg} / \mathrm{ha}$

\section{Technology and Extension gap}

The technology gap observed may be attributed to the dissimilarity in the soil fertility status and weather conditions. Hence, variety wise location specific recommendation appears to be necessary to minimize the technology gap for yield level in different situations. The extension gaps ranged from 364 to $413 \mathrm{~kg} / \mathrm{ha}$ during the period of demonstration emphasized the need to educate the farmers through various means for the adoption of improved agricultural production technologies to reverse this trend of wide extension gap. 
Table.1 Details of package of practices followed in the Cluster Front Line Demonstration

\begin{tabular}{|c|c|c|c|}
\hline S. No & Inputs & Demonstration quantity/ha & Farmers practice quantity/ ha \\
\hline 1 & Farming situation & Irrigated & Irrigated \\
\hline 2 & Variety & GNG-1581 & Unidentified \\
\hline 3 & Land preparation & Summer deep ploughing followed by rotavator & $\begin{array}{l}\text { Summer deep ploughing followed by } \\
\text { rotavator }\end{array}$ \\
\hline 4 & Time of sowing & First forth night of October & First forth night of October \\
\hline 5 & Seed treatment & Carbendazim $2 g-1$ seed+ Bio-fertilizers & No seed treatment \\
\hline 6 & Seed rate & $60 \mathrm{~kg}$ ha-1 & $80-100 \mathrm{~kg}$ ha-1 \\
\hline 7 & Method of sowing & Line sowing & Broadcasting sowing \\
\hline 8 & Nutrients application & 20:32:20:40 kg NPKS ha-1 + 16 kg ZnSO4 ha-1 & 16:46:0:0 kg NPKS ha-1 \\
\hline 9 & Weed management & Manual weeding & Manual weeding \\
\hline 10 & Pod borer control & Applied Quinolphos 25 EC @ 2.0 ml/liter Water & $\begin{array}{l}\text { Use of indiscriminate and non- } \\
\text { recommended insecticides }\end{array}$ \\
\hline
\end{tabular}

Table.2 Yield performance of chickpea under CFLDs at farmer's field

\begin{tabular}{|c|c|c|c|c|c|c|}
\hline \multirow[t]{2}{*}{ Year } & \multicolumn{2}{|c|}{ Yield kg/ha } & \multirow{2}{*}{$\begin{array}{c}\% \text { yield increase } \\
\text { over FP }\end{array}$} & \multirow{2}{*}{$\begin{array}{l}\text { Technology } \\
\text { gap (kg/ha) }\end{array}$} & \multirow{2}{*}{$\begin{array}{l}\text { Extension } \\
\text { gap (kg/ha) }\end{array}$} & \multirow{2}{*}{$\begin{array}{l}\text { Technology } \\
\text { index } \%\end{array}$} \\
\hline & Demonstration & Farmer Practice & & & & \\
\hline 2015-16 & 1710 & 1307 & 30.83 & 590 & 403 & 25.65 \\
\hline 2016-17 & 1742 & 1329 & 31.07 & 558 & 413 & 24.26 \\
\hline 2017-18 & 1712 & 1348 & 27.00 & 588 & 364 & 25.56 \\
\hline Average & 1721 & 1328 & 29.63 & 579 & 393 & 25.15 \\
\hline
\end{tabular}

Table.3 Economical comparison between recommended practice and farmers practice

\begin{tabular}{|c|c|c|c|c|c|c|c|c|}
\hline Year & \multicolumn{2}{|c|}{ Gross cost (Rs.ha-1) } & \multicolumn{2}{c|}{ Gross return (Rs. ha-1) } & \multicolumn{2}{c|}{ Net return(Rs. ha-1) } & \multicolumn{2}{c|}{ B: C Ratio } \\
\hline & Demons. & F.P. & Demons. & F.P. & Demons. & F.P. & Demons. & F.P. \\
\hline $\mathbf{2 0 1 5}-16$ & 19256 & 17654 & 68400 & 52280 & 49144 & 34626 & 3.55 & 2.96 \\
\hline $\mathbf{2 0 1 6 - 1 7}$ & 22600 & 18890 & 78384 & 49679 & 55784 & 30789 & 3.46 & 2.62 \\
\hline $\mathbf{2 0 1 7}-18$ & 23425 & 19580 & 70244 & 46976 & 46819 & 27396 & 2.99 & 2.39 \\
\hline Average & 21760 & 18708 & 72343 & 49645 & 50582 & 30937 & 3.33 & 2.65 \\
\hline
\end{tabular}

More and more use of latest production technologies with high yielding varieties will subsequently change this alarming trend of galloping extension gap. The present study are in line with Reddy AA (2010) Poonia TC and Pithia MS (2011) Mukherjee N (2013). The new technologies will eventually lead to the farmers to discontinuance of old varieties with the new technology.

\section{Technology index}

The technology index shows the feasibility of the evolved technology at the farmers' fields.
The lower value of technology index more is the feasibility of the technology.

The data (Table 2) showed that maximum technology index value $25.65 \%$ was noticed in the year $2015-16$ followed by $25.56 \%$ in 2017-18 whereas, minimum value of technology index of $24.26 \%$ in the year 201617 , it may be due to uneven weather conditions in the area.

The findings of the present study are in line with the findings of Hiremath et al., (2007) and Dhaka et al., (2010). 


\section{Economic performance}

The economics (Cost of cultivation, gross \& net return) of chickpea under Cluster front line demonstrations were estimated and the results have been presented in Table 3 .

The Cluster front line demonstrations recorded higher average gross returns (Rs. 72343 /ha) and net return (Rs. 50582/ ha) with cost: benefit ratio (3.33) compared to farmers practice as gross return Rs. 49645/ ha with higher cost: benefit ratio.

The present findings are in accordance with study of Hiremath and Nagaraju (2010), Kiresur (2011) and Kumar (2015).

\section{References}

Dhaka, B. L.; Meena, B. S. and Suwalka, R. L. (2010). Popularization of improved maize production technology through frontline demonstrations in south-eastern Rajasthan. Journal of Agriculture Science, 1(1): 39-42.

DOA (2011) Directorate of Agriculture, Gujarat State, Gandhinagar Pp.9

FAO STAT (2012) FAOSTAT - Statistical Database, 2012.

Hedge, D. M. (2004) Becoming self -reliant. Hindu survey of Indian Agriculture 2004, pp 45-47.

Hiremath SM and Nagaraju MV (2010). Evaluation of on-farm front line demonstrations on the yield of chilli, Karnataka J. Agric. Sci., 23 (2): 341- 342.

Hiremath, S. M.; Nagaraju, M. V. and Shashidhar, K. K. (2007). Impact of front line demonstrations on onion productivity in farmer's field. Paper presented In: Nation
Sem Appropriate Extn Strat Manag Rural Resources, Univ. Agric. Sci., Dharwad, December 18-20, p.100.

Jeengar KL, Panwar P and Pareek OP (2006) Front line demonstration on maize in bhilwara District of Rajsthan, Current Agriculture, 30(1/2):115- 116.

Kiresur, V.R.; RamannaRao, S.V. and Hedge, D.M. (2011). Improved technologies in oilseeds production-An assessment of their economic potentials in India. Agricultural Economic Research Review 14 (2):95-108.

Kumar, Arvind (2015). Status and future thrust areas of rape seed mustard research in India. Indian Journal of Agricultural Sciences.75 (10): 621-635.

Kumar, H. and Yadav, D.S. (2007) Effect of phosphorus and sulphur levels on growth, yield and quality of Indian mustard (Brassica juncea) cultivars. Indian Journal of Agronomy. 52(2): 154-157.

Mokidue I, Mohanty A.K., and Sanjay, K (2011) Corelating growth, yield and adoption of urd bean technologies. Indian J. Ex. Edu. 11(2): 20-24.

Mukherjee N (2013) Participatory, and action. Concept, Publishing Company, New Delhi, Pp.63-65.

Poonia TC and Pithia MS (2011) Impact of front line demonstrations of chickpea in Gujarat. Legume Res. 34(4): 304-307.

Reddy AA (2010) Regional Disparities in Food Habits and Nutritional intake in Andhra Pradesh, India, Regional and Sectoral Economic Studies Vol. 10-2.

Samui SK, Maitra S, Roy, Mondal AK and Saha D (2000) Evaluation on front line demonstration on groundnut (Arachis hypogea L.). J. of Indian Soc. of Coastal Agriculture Research 18: 180-183.

\section{How to cite this article:}

Hrish Kumar Rachhoya, Mukesh Sharma and Saini V. K. 2018. Impact of Cluster Front Line Demonstrations on Productivity and Profitability of Chickpea in Desert of Rajasthan. Int.J.Curr.Microbiol.App.Sci. 7(06): 1860-1864. doi: https://doi.org/10.20546/ijcmas.2018.706.221 